Original Research Paper

\title{
Identifikasi Dan Uji Daya Hambat Isolat Bakteri Endofit Bunga Tanaman Cengkeh (Syzygium aromaticum L.) Terhadap Bakteri Patogen
}

\author{
Citra Sepriana1 $^{1}$, Eti Sumiati ${ }^{2}$, Dwi Soelistya Dyah Jekti ${ }^{3}$, Lalu Zulkifli ${ }^{*}$ \\ ${ }^{1}$ Program Studi Keperawatan Sekolah Tinggi Ilmu Kesehatan Mataram, Indonesia \\ ${ }^{2}$ Program Studi Kebidanan Sekolah Tinggi Ilmu Kesehatan Mataram, Indonesia \\ ${ }^{3}$ Rumah Sakit Biomedika, Mataram, Indonesia \\ ${ }^{4}$ Program Studi Pendidikan Biologi dan Program Studi Magister Pendidikan IPA Universitas Mataram, Indonesia
}

DOI: $10.29303 /$ jppipa.v6i1.340

Citation: Sepriana, C., Sumiati, E., Jekti, DSD, Zulkifli, L., (2020). Identifikasi dan Uji Daya Hambat Isolat Bakteri Endofit Bunga Tanaman Cengkeh (Syzygium aromaticum L.) Terhadap Bakteri Patogen. Jurnal Penelitian Pendidikan IPA, 6(1). pp. $101-106$

\section{Article history}

Received: November $19^{\text {th }} 2019$

Revised: January $1^{\text {th }} 2020$

Accepted: January $29^{\text {th }} 2020$

*Corresponding Author:

Lalu Zulkifli: Program Studi

Pendidikan Biologi,

Universitas Mataram,

Indonesia;

Email:

lalu_zulkifli@unram.ac.id

\begin{abstract}
This study aims to determine the ability of endophytic bacteria isolated from clove plant flowers to inhibit the growth of Streptococcus mutans, Staphylococcus aureus, Klebsiella pneumoniae, Escherichia coli and to identify the relationship of endophytic bacteria related to the existing GenBank data based on 16S rRNA genes. The stages in this study were the isolation of endophytic bacteria by stratified dilution method on TSA media, inhibitory tests were carried out by using the well diffusion method on MHA media and molecular identification was based on 16S rRNA genes. Five isolates were found, in which 4 isolates have a strong inhibitory power (inhibition zone diameter $\geq 11 \mathrm{~mm}$ ) against $S$. aureus. Molecular identification based on 16S rRNA gene shows that the endophytic bacteria were related to Bacillus amyloliquefasiens MPA 1034, Staphylococcus epidermidis and Bacillus cereus JL.
\end{abstract}

Keywords: flowers of the clove plant; endophytic bacteria; 16S rRNA gene.

\begin{abstract}
Abstrak: Penelitian ini bertujuan untuk mengetahui kemampuan isolat bakteri endofit bunga tanaman cengkeh dalam menghambat pertumbuhan bakteri Streptococcus mutans, Staphylococcus aureus, Klebsiella pneumoniae, Escherichia coli dan mengidentifikasi bakteri endofit tersebut berbasis gen $16 \mathrm{~S}$ rRNA. Tahapan dalam penelitian ini adalah isolasi bakteri endofit dari bunga tanaman cengkeh dengan metode metode pengenceran bertingkat pada media TSA, uji daya hambat dilakukan dengan metode sumuran pada media MHA dan identifikasi berbasis gen $16 \mathrm{~S}$ rRNA. Hasil isolasi bakteri endofit bunga tanaman cengkeh didapatkan 5 isolat, 4 isolat diantaranya memiliki daya hambat kuat (diameter zona hambat $\geq$ $11 \mathrm{~mm}$ ) terhadap bakteri $S$. aureus. Identifikasi molekuler berbasis gen 16S rRNA menunjukkan bahwa isolat bakteri endofit bunga tanaman cengkeh tersebut berkerabat dengan Bacillus amyloliquefasiens MPA 1034, Staphylococcus epidermidis dan Bacillus cereus JL.
\end{abstract}

Kata kunci: bunga tanaman cengkeh, bakteri endofit, gen 16S rRNA

\section{Pendahuluan}

Pengambilan senyawa bioaktif dari suatu tanaman obat umumnya dapat dilakukan dengan mengekstrak bagian tanaman. Cara ini tentu kurang efektif, karena apabila tanaman obat tersebut terus- menerus diambil untuk diekstrak senyawa bioktifnya, maka ketersedian tanaman tersebut di lingkungan akan menurun. Cara efisien yang dapat dilakukan untuk memperoleh senyawa bioaktif tersebut adalah menggunakan mikroba endofit yang mampu 
menghasilkan sejumlah senyawa bioaktif yang dibutuhkan (Simarmata et al., 2007).

Mikroorganisme yang hidup dalam jaringan tumbuhan disebut mikroba endofit. Mikroba endofit dapat berupa jamur atau bakteri, yang diperoleh dari bagian dalam tumbuhan yang mampu menghasilkan sejumlah senyawa bioaktif yang sama dengan senyawa bioaktif tumbuhan tanpa harus mengekstraksi bagian tumbuhan (Sumampouw et al., 2014).

Menurut Tan dan Zou (2001), bakteri endofit dapat menghasilkan senyawa bioaktif yang karakternya mirip atau sama dengan senyawa yang diproduksi oleh tumbuhan inangnya. Senyawa bioaktif bakteri endofit dapat dimanfaatkan sebagai antibakteri, antifungi, antivirus, antikanker, antidiabetes, antimalaria, dan anti imunosupresif (Strobel, 2003). Saat ini sangat diperlukan senyawa bioaktif (antibakteri) baru yang lebih baik dari sebelumnya (Sumiati, 2014).

Cengkeh (Syzygium aromaticum) termasuk salah satu tanaman obat tradisional yang banyak dimanfaatkan di Indonesia. Tanaman cengkeh memiliki kandungan minyak yang cukup tinggi dan mempunyai sifat khas yaitu semua bagiannya mulai dari akar, batang, daun, sampai dengan bunganya mengandung minyak atsiri (Kumala dan Indriani, 2008).

Minyak cengkeh mengandung eugenol, caryophyllene, eugenol acetate, dan alpha humelene. Komponen utama dan bahan aktif dalam minyak cengkeh ialah eugenol (Ayoola et al., 2008). Minyak cengkeh telah terbukti memiliki aktivitas antibakteri, anti inflamasi, analgesik, antioksidan, dan anti jamur (Rochyani et al., 2007; Ali et al., 2009; Pramod et al., 2010; Andries et al., 2014). Penelitian Sepriana et al (2017), menunjukkan bahwa isolat bakteri endofit dari kulit batang tanaman cengkeh memiliki kemampuan sebagai antibakteri.

Bunga cengkeh memiliki banyak khasiat untuk pengobatan, diantaranya untuk mengatasi sakit kepala, penyakit jantung, stroke, radang lambung (gastritis), asam urat, sakit gigi, sinusitis, dan batuk. Selain itu bermanfaat untuk mengatasi perut mulas dan mual (Herliana, 2013).

Penelitian ini bertujuan untuk mengetahui kemampuan isolat bakteri endofit bunga tanaman cengkeh dalam menghambat pertumbuhan bakteri patogen $S$. mutans, S. aureus, K. pneumoniae, dan E. coli dan mengidentifikasi jenis bakteri endofit bunga tanaman cengkeh yang memiliki daya hambat.

\section{Metode}

\section{Isolasi bakteri endofit}

Isolasi bakteri endofit dari bunga tanaman cengkeh dilakukan dengan metode pengenceran bertingkat Zinniel et al (2000). Sampel bunga tanaman cengkeh dicuci dengan air mengalir, dikeringkan dengan tisu, dan ditimbang sebanyak 1 gram, kemudian disterilisasi permukaannya dengan alkohol $70 \%$ selama 30 detik, kemudian dicelupkan dalam larutan $\mathrm{NaOCl} 4 \%$ selama 2 menit, selanjutnya dicuci dengan aquades steril. Bunga yang sudah steril dihaluskan menggunakan mortal steril dan ditambahkan $9 \mathrm{ml} \mathrm{NaCl}$ 0,9\% steril. Sebanyak $1 \mathrm{ml}$ bunga dimasukkan ke dalam tabung reaksi berisi $9 \mathrm{ml}$ $\mathrm{NaCl}$ 0,9\% steril, kemudian dikocok hingga homogen, selanjutnya diambil $1 \mathrm{ml}$ ekstrak dan dilakukan pengenceran secara berseri sampai $10^{-3}$. Sebanyak 0,1 $\mathrm{ml}$ dari setiap pengenceran diinokulasikan pada media TSA. Koloni yang menunjukkan perbedaan tipe morfologi kemudian dimurnikan pada media TSA (Balosi et al., 2014).

\section{Uji daya hambat bakteri endofit}

Isolat bakteri endofit diinokulasi ke dalam medium NB, diinkubasi pada suhu $32^{\circ} \mathrm{C}$ sambil digoyang selama 48 jam, dan disentrifugasi pada 5000 g selama 30 menit sehingga dihasilkan supernatan. Bakteri uji yang digunakan ada 4 jenis bakteri yaitu Streptococcus mutan, Staphylococcus aureus, Escherichia coli dan Klebsiella pneumoniae. Bakteri uji dibuat pengenceran menggunakan $\mathrm{NaCl} 0,9 \%$ dan kekeruhannya distandarisasi dengan CFU $10^{5}$. Uji daya hambat dilakukan dengan metode sumuran pada media MHA, kontrol positif menggunakan ciprofloxacin dan kontrol negatif dengan aquades (Prayoga, 2013).

\section{Identifikasi molekuler isolat bakteri endofit}

Ekstraksi DNA dilakukan dengan menambahkan 2 ose isolat bakteri endofit dalam $200 \mu \mathrm{l}$ DNAzol, dikocok kuat sebanyak 10 kali, ditambahkan etanol $100 \%$ sebanyak $100 \mu$ l. Larutan bakteri endofit tadi disentrifugasi pada $12.000 \mathrm{~g}$ selama 5 menit. Pelet hasil sentrifugasi ditambahkan etanol $80 \%$ sebanyak $200 \mu \mathrm{l}$ kemudian disentrifugasi pada $9000 \mathrm{~g}$ selama 3 menit (dilakukan 2 kali). Hasil sentrifugasi (pellet) ditambahkan aquades $50 \mu \mathrm{l}$ dan disimpan pada $-20^{\circ} \mathrm{C}$ sampai saat digunakan.

Amplifikasi gen 16S rRNA dilakukan menggunakan primer 63f (5'-CAG GCCTAA CACATG CAA GTC-3') dan 1387r (5'-GGG CGG WGT GTA CAAGGC-3') (Marchesi et al., 1998). Amplifikasi DNA dilakukan dengan alat PCR My Cycler (Bio Rad). Kondisi awal (pre) PCR diatur pada suhu $94^{\circ} \mathrm{C}$ selama 5 menit, selanjutnya diikuti dengan 35 siklus PCR yang terdiri dari denaturasi pada suhu $94^{\circ} \mathrm{C}$ selama 30 detik, annealing pada suhu $55^{\circ} \mathrm{C}$ selama 30 detik dan extention pada suhu $72^{\circ} \mathrm{C}$ selama 45 detik, setelah 35 siklus terlampaui, dilakukan post $\mathrm{PCR}$ pada suhu $72^{\circ} \mathrm{C}$ selama 5 menit. Elektroforesis dilakukan pada $2 \%$ gel agarose dengan tegangan $100 \mathrm{~V}$ dan kuat 
arus sebesar 400 A selama 30 menit. Marker yang di pakai adalah 100 bp DNA Ladder (Invitrogen). Hasil elektroforesis difoto menggunakan alat Bio Rad (Aris et al., 2013).

Produk PCR selanjutnya disekuensing di 1stBase Malaysia melalui PT Genetika Science Jakarta.Data sekuen dibandingkan dengan sekuen yang ada pada GenBank dengan metode BLAST yang terdapat pada situs NCBI (http://www.nebi.nml.nih.gov), dan selanjutnya dianalisis dengan menggunakan software MEGA6 untuk konstruksi phylogenetic tree dan penentuan kekerabatan dari isolat yang diperoleh.

\section{Hasil dan Pembahasan}

Hasil isolasi bakteri endofit dari bunga tanaman cengkeh ditemukan 5 isolat bakteri endofit. Hasil uji daya hambat dari 5 isolat bakteri endofit tersebut menunjukkan 4 isolat ( $\mathrm{BC} 1, \mathrm{BC} 2, \mathrm{BC} 3, \mathrm{BC} 4)$ yang memiliki aktivitas daya hambat terhadap $S$. aureus (Tabel 1)

Tabel 1. Hasil pengukuran diameter zona hambat bakteri endofit bunga tanaman cengkeh

\begin{tabular}{|c|c|c|c|c|c|}
\hline \multirow[b]{2}{*}{ NO } & \multirow[b]{2}{*}{ Isolat bakteri endofit } & \multicolumn{4}{|c|}{ Rata-rata diameter zona hambat (mm) } \\
\hline & & $\begin{array}{l}\text { Streptococcus } \\
\text { mutan }\end{array}$ & Staphylococcus aureus & Eschericia coli & $\begin{array}{l}\text { Klebsiella } \\
\text { pneumoniae }\end{array}$ \\
\hline 1 & $\mathrm{BC} 1$ & - & 13.8 & - & - \\
\hline 2 & $\mathrm{BC} 2$ & - & 14.3 & - & - \\
\hline 3 & $\mathrm{BC} 3$ & - & 11 & - & - \\
\hline 4 & $\mathrm{BC} 4$ & - & 14 & - & - \\
\hline 5 & Kontrol + & 25.3 & 27.6 & 34.6 & 26.6 \\
\hline 6 & Kontrol - & - & - & - & - \\
\hline
\end{tabular}

Keterangan:

$\mathrm{BC}=$ isolat bakteri endofit bunga cengkeh

Kontrol positif $(+)=$ ciprofloxacin

Kontrol negatif $(-)=$ aquades

Hasil pengukuran diameter zona hambat isolat bakteri endofit menunjukkan bahwa isolat bakteri endofit bunga tanaman cengkeh memiliki potensi antibakteri yang kuat (sensitif), dimana diameter daya hambat yang paling besar adalah 14,3 mm (BC2) dan diameter daya hambat yang paling kecil adalah $11 \mathrm{~mm}$ (BC3). Menurut Susanto et al (2012) daya hambat dengan diameter 11-20 $\mathrm{mm}$ memiliki potensi antibakteri kuat (sensitif). Zona hambat merupakan aktivitas dari metabolit sekunder bakteri endofit dalam menghambat pertumbuhan bakteri uji dengan cara mengganggu metabolisme bakteri, menghambat sintesis dinding sel bakteri, menganggu permeabilitas membran sel bakteri, menghambat sintesis protein bakteri dan merusak sintesis asam nukleat bakteri uji (Brooks et al., 2005).

Hasil analisis molekuler isolat bakteri endofit bunga tanaman cengkeh menunjukkan adanya pita DNA penyandi gen 16S rRNA sejajar pada ukuran \pm 1324 bp (Gambar 1) setelah dibandingkan dengan DNA marker (100 bp DNA ladder).
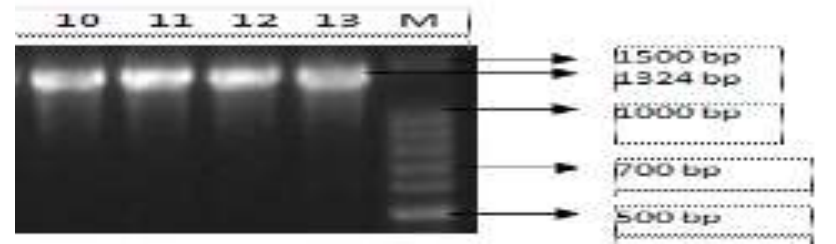

Gambar 1. Hasil elektroforesis dari Amplifikasi 16S rRNA isolat bakteri endofit bunga (BC) tanaman cengkeh dibandingkan dengan DNA marker (100 bp DNA ladder), dengan ukuran pita DNA \pm 1324 bp. M (DNA marker), 10 (BC1), 11 (BC2), 12 (BC3), 13 (BC4).
Identifikasi dilanjutkan dengan melakukan sekuensing, hasil sekuensing gen 16S rRNA dari isolat bakteri endofit kemudian dibandingkan dengan database yang ada di GenBank. Hasil perbandingan sekuensing ini kemudian divisualisasikan dalam bentuk pohon filogenetik berdasarkan jarak evolusi atau jarak genetik (Tabel 2) dengan menggunakan program MEGA 6 yang dapat menunjukkan kekerabatan isolat sampel dengan sekuen yang diperoleh.

Tabel 2. Jarak genetik (genetic distance) isolat bakteri endofit bunga tanaman cengkeh terhadap bakteri referensi yang diakses dari GenBank.

\begin{tabular}{llll}
\hline No & $\begin{array}{l}\text { Isolat } \\
\text { Bakteri } \\
\text { Endofit }\end{array}$ & $\begin{array}{l}\text { Jarak } \\
\text { Genetik }\end{array}$ & $\begin{array}{l}\text { Bakteri Referensi/ } \\
\text { Kekerabatan }\end{array}$ \\
\hline 1 & BC1 & 0,00 & $\begin{array}{l}\text { Bacillus } \\
\text { amyloliquefasiens }\end{array}$ \\
2 & BC2 & 0,015 & $\begin{array}{l}\text { MPA 1034 } \\
\text { Staphylococcus } \\
\text { epidermidis }\end{array}$ \\
3 & BC3 & 0,009 & $\begin{array}{l}\text { Bacillus cereus JL } \\
\text { Staphylococcus } \\
\text { epidermidis }\end{array}$ \\
\hline
\end{tabular}

Berdasarkan jarak genetik (Tabel 2) dan pohon filogenetik (Gambar 2), isolat bakteri endofit bunga tanaman cengkeh secara molekuler terdiri dari 2 genus yaitu Bacillus dan Staphylococcus. Isolat bakteri endofit dari bunga tanaman cengkeh yaitu isolat $\mathrm{BC} 1$ memiliki kekerabatan dengan B. amyloliquefaciens MPA 1034, isolat BC3 dengan Bacillus cereus JL dan 
isolat BC2 dan BC4 dengan Staphylococcus epidermidis.

Data urutan basa gen penyandi 16S rRNA memungkinkan digunakan untuk mengkonstruksi pohon filogenetik yang dapat menunjukkan nenek moyang dan hubungan kekerabatan organisme (Ward, 1998).

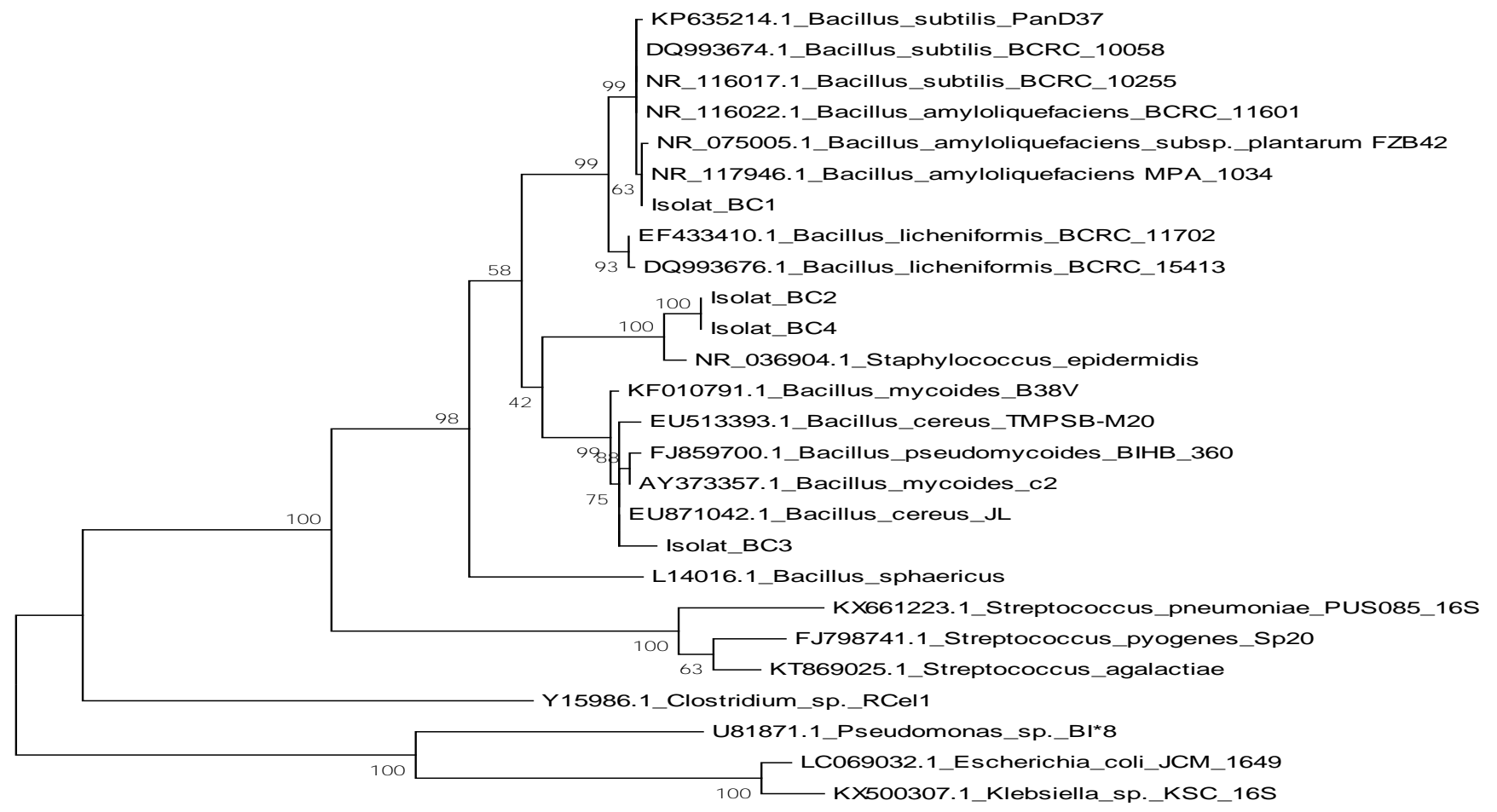

$\longmapsto 0.05$

Gambar 2. Pohon Filogenetik Berdasarkan Sekuen Gen 16S rRNA dari Isolat-Isolat Bakteri Endofit Bunga Tanaman Cengkeh

Isolat bakteri endofit bunga tanaman cengkeh yang didapatkan memiliki daya hambat terhadap $S$. aureus, artinya ketiga bakteri yang diperoleh berdasarkan identifikasi molekuler yaitu bakteri $B$. amyloliquefaciens, B. cereus JL dan Staphylococcus epidermidis dapat mengahambat bakteri $S$. aureus. Kemampuannya untuk menghambat karena adanya senyawa metabolit yang dimiliki isolat bakteri endofit. Hal ini sesuai dengan pernyataan Backman dan Sikora (2008), yaitu senyawa yang dikeluarkan mikroba endofit berupa senyawa metabolit sekunder yang merupakan senyawa bioaktif dan dapat berfungsi untuk membunuh patogen. Mikroba endofit memiliki prospek yang baik dalam penemuan sumber-sumber senyawa bioaktif yang dalam perkembangan lebih lanjut dapat dijadikan sebagai sumber penemuan obat untuk berbagai macam penyakit.

Penelitian Suryadi et al. (2015), menunjukkan bahwa $B$. cereus $11 \mathrm{UJ}$ menghasilkan 3 senyawa utama, yaitu 9,19-cyclolanostan-3-ol, acetate, (3.beta.)-(CAS) cycloartanyl acetate (13.14\%); 4(2',2'-dimethyl-6'-methyliden-1'-cyclohexyliden)-3-

methyl-2-butanone (9.72\%); dan stigmast-5-en-3-ol, oleat $(9.09 \%)$. Metabolit sekunder yang dihasilkan dari ekstrak bakteri $B$. cereus $11 \mathrm{UJ}$ dapat menghambat pertumbuhan cendawan $R$. solani dan $P$. oryzae.
B. amyloliquefaciens strain FZB42 diketahui mampu mensekresikan senyawa bakteriosin kelas 1 yaitu lantibiotic mersacidin yang tersusun atas 20 asam amino. Mersacidin ini akan mengikat prekursor lipid II kemudian menghambat biosintesis dinding sel bakteri sehingga bakteri patogen tidak akan bisa bertahan dan beregenerasi (Herzner et al., 2011).

Senyawa benzena dan benzothiazoles fenol dan 2,3,6-trimetil-fenol asal metabolit sekunder $B$. amyloliqueafaciens NJN-6 dilaporkan mempunyai aktivitas anticendawan terhadap $F$. oxysporum. Secara in vitro senyawa alkohol aldehida, ester, eter, dan naftil pada konsentrasi $200 \mu \mathrm{L}$ hampir sepenuhnya menghambat $F$. oxysporum, sedangkan keton diproduksi pada tingkat tinggi (Yuan et al. 2012).

Penelitian Handini dan Nawangsih (2014) yaitu menentukan keefektifan bakteri endofit dan bakteri perakaran pemacu pertumbuhan tanaman sebagai agens hayati untuk penyakit layu bakteri pada tomat. Dua isolat bakteri perakaran pemacu pertumbuhan tanaman yaitu Pseudomonas fluorescence RH4003, Bacillus subtilis AB89, dan 4 isolat bakteri endofit yaitu BC10, B. amyloliquefaciens, dan Staphylococcus epidermidis $\mathrm{BC} 4$, diaplikasikan secara tunggal atau bersama-sama (perlakuan kombinasi). Bakteri endofit dan bakteri perakaran pemacu pertumbuhan tanaman 
dan diaplikasikan secara tunggal yang memberikan penekanan relatif paling tinggi ialah $S$. epidermidis BC4 dan P. fluorescens RH4003. Aplikasi campuran bakteri agens hayati yang memberikan penekanan terhadap perkembangan penyakit paling tinggi adalah campuran antara $B$. subtilis AB89 dan $B$. amyloliquefaciens BL10.

\section{Kesimpulan}

Isolat bakteri endofit dari bunga tanaman cengkeh mempunyai daya hambat terhadap bakteri Staphylococcus aureus sebanyak 4 isolat. Isolat bakteri endofit bunga tanaman cengkeh memiliki kekerabatan dengan Bacillus amyloliquefaciens MPA 1034, Staphylococcus epidermidis dan Bacillus cereus JL.

\section{Daftar Pustaka}

Ali, H.S., M. Kamal and S.B. Mohamed. 2009. Invitro Clove Oil Activity Againts Periodontopathic Bacteria. Journal of Science Technology 10 (1) : 1-7.

Andries, J.R., Gunawan, P.N., Supit, A. 2014. Uji Efek Bakteri Bunga Cengkeh terhadap Bakteri Streptococcus mutans Secara In Vitro. Jurnal eGIGI (eG). Vol.2 (2): 1-8

Aris, M., Sukenda, Harris, E., Sukadi, MF., Yuhana, M. 2013. Identifikasi molekular bakteri patogen dan desain primer PCR. Budidaya Perairan. Vol. 1, No. 3: 43-50.

Ayoola, G.A., Lawore, F.M., Adelowotan, T., Aibinu, I.E., Adenipekun, E., Coker, H.A.B., Odugbemi, T.O,. 2008. Chemical Analysis and Antimicrobial Activity of The Essential Oil Syzigium aromaticum (Clove). Afr. J. Microbiol. Res. Vol.(2) pp. 162-166.

Backman PA, dan Sikora RA. 2008. Endophytes: an emerging tool for biological control. Biol Control. 46(1):1-3. doi:10.1016/j.bio control.2008.03.009

Balosi F, Lakani I, Panggeso J. 2014. Eksplorasi Bakteri Endofit Sebagai Agens Pengendalian Hayati Terhadap Penyakit Darah Pada Tanaman Pisang Secara In-Vitro. e-J. Agrotekbis. 2 (6) : 579-586.

Brooks, Geo, Janet S. Butel, L. Nicholas Ornston. 2005. Mikrobilologi Kedokteran. Jakarta: EGC.

Handini ZVT dan Nawangsih AA., 2014. Keefektifan bakteri endofit dan bakteri perakaran pemacu pertumbuhan tanaman dalam menekan penyakit layu bakteri pada tomat. Jurnal fitopatologi Indonesia. ISSN: 2339-2479. Vol. 10 No. 2

Herliana, E. 2013. Penyakit Asam Urat Kandas Berkat Herbal. FMedia (Imprint Agro Media Pustaka). Jakarta.
Herzner, A. M., J. Dischinger, C. Szekat, M. Josten, S. Schmitz, A. Yake' le ba, R. Reinartz, A. Jansen, H. G. Sahl, J. Piel and G. Bierbaum . 2011. Expression of the Lantibiotic Mersacidin in Bacillus amyloliquefaciens FZB42. Plos one Journal, 6(1): 1-8.

Kumala, S.dan Indriani, D., 2008. Efek Antibakteri Ekstrak Etanol Daun Cengkeh (Eugenia aromaticum L). Jurnal Farmasi Indonesia. Vol.4. (2): 82-87.

Marchesi JR, Sato T, Weightman AJ, Martin TA, Fry JC, Hiom SJ, Wade WG. 1998. Design and evaluation of useful bacterium-specific PCR primers that amplify genes coding for bacterial 16S rRNA. Appl Environ. Microbiol 64:795-9.

Pramod, K., Ansari, S.H., Ali., J. 2010. Eugenol: A Natural Compound with Versatile Pharmacological Actions. J. Natural Product Communications 5(12) : 199-206.

Prayoga, E. 2013.Perbandingan Efek Ekstrak Daun Sirih Hijau (Piper betle L) Dengan Metode Difusi Disk Dan Sumuran Terhadap Pertumbuhan Bakteri Staphylococcus aureus.Fakultas Kedokteran dan Ilmu Kesehatan Universitas Islam Negeri Syarif Hidayatullah. Jakarta.

Rochyani, L., Aprilia dan M.W. Astuti. .2007. Daya Anti Bakteri Bahan Tumpatan Sementara Zinc Oxide Eugenol. DENTAL Jurnal Kedokteran Gigi FKG-UHT 1(2) : 96-99.

Sepriana, C., jekti, DSD., Zulkifli,L. 2017. Bakteri Endofit Kulit Batang Dan Bunga Tanaman Cengkeh (Syzygium aromaticum L.) Dan Kemampuannya Sebagai Antibakteri. Jurnal Penelitian Pendidikan IPA. Vol.3 (2).

Simarmata R, Lekatompessy S, Sukiman H. 2007. Isolasi Mikroba Endofitik Dari Tanaman Obat Sambung Nyawa (Gymura procumbens) Dan Analisis Potensinya Sebagai Antimikroba. Berk. Penel. Hayati: 13 (85-90).

Strobel, G.A., 2003. Endophytes as Sources of Bioactive Products, Microb.Infect., 5, 535-544.

Sumampouw, M., Bara R., Awaloei H., Posangi J., 2014. Uji Efek Antibakteri Jamur Endofit Akar Bakau Rhizophora stylosa Terhadap Bakteri Staphylococcus aureus dan Escherichia coli. Bagian Farmakologi Dan Terapi Fakultas Kedokteran Universitas Sam Ratulangi.

Sumiati, E., 2014. Uji Aktivitas Antibakteri Ekstrak Kloroform dan Ekstrak Etanol Bii Bidara Laut (Strichnos ligustrina BI) terhadap Staphylococcuc aureus ATCC 25923 dan Salmonella thypi. Jurnal Ilmiah Biogenesis. Vol. 2 (1): 1-10.

Suryadi Y, Samudra IM, Priyatno TP, Susilowati, DN, Lestari P, Sutoro. 2015. Aktivitas Anticendawan 
Bacillus cereus 11UJ terhadap. Jurnal Fitopatologi. ISSN: 0215-7950 Volume 11, Nomor 2

Susanto, D. Sudrajat dan R. Ruga. 2012. Studi kandungan bahan aktif tumbuhan meranti merah (Shorea leprosula Miq) sebagai sumber senyawa antibakteri. Mulawarmnan Scientifie 11(2): 181190.

Tan, R.X and Zou, W.X. (2001). Endophytes: a Such Source of Functional Metabolites. Natural Product Rep. 18:448-459.

Ward, D.M. 1998. A natural species concepts for procaryotes. Current Opinion in Microbiology 1: 271-277.
Yuan J, Raza W, Shen Q, Huang Q. 2012. Antifungal activity of Bacillus amyloliquefaciens NJN-6 volatile compounds against Fusarium oxysporum f. sp. cubense. Appl Environ Microbiol.78(16):5942-5944 DOI: http://dx.doi.org/10.1128/AEM.01357-12

Zinniel DK, Lambrecht P, Beth Harris N, Feng Z, Kuczmarski D, Higley P, Ishimaru CA, Arunakumari A, Barletta RG, Vidaver AK. 2002. Isolation and characterization of endophytic colonizing bacteria from agronomic crops and prairie plants. Appl Environ Microbiol. 68(5):2198-2208. 